\title{
The Influence of CBI Teaching on Students' English Translation Ability
}

\author{
Xiaofang Wang ${ }^{1, a}$ and Cheng Liu, ${ }^{2, *}$
}

School of Humanities, Jiangxi University of TCM, No. 1688 of Meiling Road, Wanli District, Nanchang City, Jiangxi Province, China

School of Humanities, Jiangxi University of TCM, No. 1688 of Meiling Road, Wanli District, Nanchang City, Jiangxi Province, China

a920711622@qq.com, bjxjzlc@163.com

Keywords: TCM English; Curriculum reform; CBI teaching mode

\begin{abstract}
Content-based Instruction (CBI) is a kind of professional English teaching method which combines the specific topic or the academic content with the purpose of language teaching, and combines the language teaching with the content of the subject. This study analyzed the Traditional Chinese Medicine (TCM) English based on CBI teaching mode in TCM universities, to explore how to carry out TCM English course reform to improve the students' English translation ability and promote their language skills in the professional field of TCM, and improve the quality of English teaching.
\end{abstract}

\section{Introduction}

Content-based instruction (CBI) is a significant approach in language education ${ }^{[1]}$. It is aimed to provide second-language learners instruction in content and language. CBI is a series of foreign language teaching concepts and teaching modes which are combined with the information of language teaching and learners' need to master the information of subject content or learners' interest ${ }^{[2]}$. As a second language learning methods, CBI began in 1960s, and began popular in Europe and the United States in $1970 \mathrm{~s}^{[3]}$.

It focuses on the students to learn the content or to obtain the information, rather than the target language itself, grammar, vocabulary and other teaching elements.

This concept puts more emphasis on language system and the teaching content of the organic integration, and learning content is used as language learning and carrier of language environment, so that the target language becomes means or tools of related content, which is more in line with the majority of second language learning orientation.

\section{The Application of CBI in Traditional Chinese Medicine English}

This study employs CBI teaching method in English courses, and selects students who major in TCM to learn TCM English. The teacher designs classroom activities or tasks through TCM course content. The teacher not only emphasizes learning subject content, but also pays attention to regulating students' English language using, reaching the interactions between language and the teaching content, students' interactions with the language environment and the interactions between teachers and students.

Research Object. The object of this study is 50 sophomores from class of TCM, Clinical Medical College of Jiangxi University of Traditional Chinese Medicine. Class II of TCM is selected as the experimental class, and class I of TCM is the control class. These two classes have the same class periods and the same teacher. Previous data analysis showed that the two classes have similar English translation level (Table I).

The Purpose of the Study. Through the experimental comparison, it was to study the effect of CBI teaching method in improving the students' English translation ability and its advantages.

The Research Process. CBI teaching model was used in the experimental group, adapting Professional English for Traditional Chinese Medicine written by Liu Ming as the text book. The control 
group employed traditional teaching methods, using College English (Book Four) as the text book to learn general English course. The study lasted one semester, 2 periods in a week, and 30 periods in all. The research tool was a questionnaire survey, an interview and a translation test. There are 35 questions in the questionnaire survey, which involves students' suggestions and views on CBI English class. Translation tests are derived from the College English Test Band-4 (CET-4), which can ensure the reliability and validity of the test. The experimental class and control class were tested before and after the experiment, the total score of the translation test was 70. The experimental class was required to take the questionnaire survey and the interview after the experiment. The software of SPSS 17.0 was used to analyze the experimental results and statistical analysis, and the research data are listed as follows:

Table 1. Results of mean scores

\begin{tabular}{|l|l|l|l|l|l|}
\hline & Class & $\mathrm{N}$ & Mean & Std. Deviation & $\begin{array}{l}\text { Std. Error } \\
\text { Mean }\end{array}$ \\
\hline \multirow{3}{*}{ Pre-test } & experimental class & 50 & 42.79 & 3.513 & 1.927 \\
\cline { 2 - 7 } & control class & 50 & 43.05 & 3.139 & \\
\hline \multirow{3}{*}{ Post test } & experimental class & 50 & 53.97 & 3.431 & 2.730 \\
\cline { 2 - 7 } & control class & 50 & 45.06 & 3.215 & 2.105 \\
\hline
\end{tabular}

Table 2. T-test of the scores in the two groups

\begin{tabular}{|c|c|c|c|c|c|c|}
\hline & \multicolumn{5}{|c|}{ Paired Difference } & \multirow{3}{*}{ Sig(2-tailed ) } \\
\hline & \multirow{2}{*}{ Mean } & \multirow{2}{*}{$\begin{array}{l}\text { Std. } \\
\text { Deviation }\end{array}$} & \multirow{2}{*}{$\begin{array}{l}\text { Std. Error } \\
\text { Mean }\end{array}$} & \multicolumn{2}{|c|}{$\begin{array}{l}\text { 95\% Confidence Interval of the } \\
\text { Difference }\end{array}$} & \\
\hline & & & & Lower & Upper & \\
\hline $\begin{array}{l}\text { Pair } \\
\text { Pre-test-post } \\
\text { test }\end{array}$ & -8.91 & 5.377 & .832 & -9.869 & -7.253 & .000 \\
\hline
\end{tabular}

From table 1, we can see that the mean score in control group is 43.05 , and the mean score in experimental group is 42.79. Their translation achievements before the experiment have little difference; however, the mean score of the experimental group increases significantly faster than that in the control group after the experiment. The mean score of experimental group is 53.97, and that of control group is 45.06. From table II, after a semester's experiment, there is significant difference between the two groups $(\mathrm{P}=0.000)$, indicating that in the experimental group students' English translation ability improved greatly after using the CBI teaching method. Compared with the control group, the English translation ability in the experimental group is higher, more accurate in wording using.

\section{Discussion}

Statistics show that the experimental group in the English translation level, expression performance is better than the control group. Although the English translation level and skills of the control group were improved after the test, the degree of improvement was smaller than that of the experimental group.

CBI teaching concept emphasizes the combination of content and language skills, the use of authentic meaningful materials, to provide a platform for language skills training. Research shows that: the CBI teaching method puts students' and social demand in the first place, and plays a connecting link between 
the basic English teaching and the students' academic study. It also lays a good foundation to help students adapt to the medical work in the future, to improve their English comprehensive application ability and academic research level. However, it is time consuming to choose the language materials that can be understood by students, and the classroom design also requires a certain degree of energy, and the balance of content and language should be paid attention to.

10 respondents of the experimental group students reflect that they like this kind of teaching model very much, the flexible and diverse classroom let their immense interest, and learning enthusiasm and initiative improve greatly.

\section{Conclusion}

In general, CBI teaching mode provides the subject content that learners need and the learners are interested in it. It can promote learners to have more strong learning desire, and use more effective learning strategies actively. Compared with the traditional English teaching mode, this mode can improve the students' translation ability and their comprehensive ability of English. Of course, the mode brings new problems which also need to be further tested and improved in teaching practice.

CBI teaching mode requires teachers to use real, meaningful teaching materials, which requires teachers to collect resources, to create a real environment, to stimulate learners' interest in learning. In addition, teachers might expand the students' professional terminology and knowledge, and introduce the cultural background and habits of many countries, so that students can improve their English communicative ability. Teachers can provide a wide range of professional terms in the real English environment, to ensure that students have a sufficient amount of professional terminology vocabulary. What's more, teachers should apply the student-oriented teaching design which encourages all students to participate in the activities in and out of class. Teachers might require students to participate in all aspects of teaching, and organize some small class group competitions, to enhance students' cooperation and competition consciousness, which may help the students to experience the joy of success, to stimulate students' interest in learning English.

\section{Acknowledgements}

Key project of Teaching Reform of Jiangxi University of traditional Chinese Medicine in 2016 (No.2016jzzd-1); Special Social Science Planning Project of Foreign Language Teaching and Research of Universities and Colleges in Jiangxi Province (No.15WX201); Study of English translation of basic terms of Traditional Chinese Medicine based on corpus (YY162002).

\section{References}

[1] Brinton, D. M., Snow, M. A., \& Wesche, M. B. Content-based second language instruction. New York: Newbury House, 1989.

[2] Richards, J. C \& Rodgers, T. S. Approaches and Methods in Language Teaching: A Descriptions and Analysis. New York: Cambridge University Press, 2001: 291-300.

[3] Qingning DAI. CBI teaching idea and its teaching mode. ForeignLanguageTeachingAbroad, 2004, (4): $16-20$. 